\title{
Developing and Testing a Measure for the Ethical Culture of Organizations: The Corporate Ethical Virtues Model
}

\author{
Muel Kaptein
}

\begin{tabular}{|l|l|}
\hline \multicolumn{2}{|l|}{ ERIM REPORT SERIES RESEARCH IN MANAGEMENT } \\
\hline ERIM Report Series reference number & ERS-2007-084-ORG \\
\hline Publication & December 2007 \\
\hline Number of pages & 45 \\
\hline Persistent paper URL & http://hdl.handle.net/1765/10770 \\
\hline Email address corresponding author & mkaptein@rsm.nl \\
\hline Address & Erasmus Research Institute of Management (ERIM) \\
& RSM Erasmus University / Erasmus School of Economics \\
& Erasmus Universiteit Rotterdam \\
& P.O.Box 1738 \\
& 3000 DR Rotterdam, The Netherlands \\
& Phone: + 31104081182 \\
& Fax: $\quad+31104089640$ \\
& Email: info@erim.eur.nl \\
& Internet: www.erim.eur.nl \\
\hline
\end{tabular}

Bibliographic data and classifications of all the ERIM reports are also available on the ERIM website: www.erim.eur.nl 


\section{ERASMUS RESEARCH INSTITUTE OF MANAGEMENT}

\section{REPORT SERIES}

\section{RESEARCH IN MANAGEMENT}

\begin{tabular}{|l|l|}
\hline \multicolumn{2}{|l|}{ ABSTRACT AND KEYWORDS } \\
\hline Abstract & $\begin{array}{l}\text { Based on four interlocking empirical studies, this paper initially validates and refines the } \\
\text { Corporate Ethical Virtues Model which formulates normative criteria for the ethical culture of } \\
\text { organizations. The findings of an exploratory factor analysis provide support for the existence of } \\
\text { eight unidimensional subscales: clarity, congruency of supervisors, congruency of management, } \\
\text { feasibility, supportability, transparency, discussability, and sanctionability. The findings of a } \\
\text { confirmatory factor analysis show that the overall fit of the model is quite high. Evidence of } \\
\text { convergent and discriminant validity is also found. The resulting 58-tem self-reporting } \\
\text { questionnaire is a useful tool that can be used in future research and by managers in assessing } \\
\text { the ethical culture of their organization. }\end{array}$ \\
\hline Free Keywords & ethics, culture, virtues, construct development, factor analysis \\
\hline Availability & $\begin{array}{l}\text { The ERIM Report Series is distributed through the following platforms: } \\
\text { Academic Repository at Erasmus University (DEAR), DEAR ERIM Series Portal } \\
\text { Social Science Research Network (SSRN), SSRN ERIM Series Webpage } \\
\text { Research Papers in Economics (REPEC), REPEC ERIM Series Webpage }\end{array}$ \\
\hline Classifications & $\begin{array}{l}\text { The electronic versions of the papers in the ERIM report Series contain bibliographic metadata } \\
\text { by the following classification systems: } \\
\text { Library of Congress Classification, (LCC) LCC Webpage } \\
\text { Journal of Economic Literature, (JEL), JEL Webpage } \\
\text { ACM Computing Classification System CCS Webpage } \\
\text { Inspec Classification scheme (ICS), ICS Webpage }\end{array}$ \\
\hline
\end{tabular}




\title{
Developing and testing a measure for the ethical culture of
} organizations:

\section{the corporate ethical virtues model}

\author{
Muel Kaptein \\ Business-Society Department \\ RSM Erasmus University \\ Room T07-07 \\ P.O. Box 1738 \\ 3000 DR Rotterdam \\ The Netherlands \\ Tel.: +31 104082823 \\ E-mail: mkaptein@rsm.nl
}

\section{Author biography}

Muel Kaptein, $\mathrm{PhD}$, is Professor of Business Ethics and Integrity Management at the Department of Business-Society Management at RSM Erasmus University. His research interests include the management of ethics, the measurement of ethics and the ethics of management. He has published papers in the Journal of Business Ethics, Organization Studies, Corporate Governance, Journal of Management Studies, Business \& Society, and Academy of Management Review. He is the author of the books Ethics Management (Springer, 1998), The Balanced Company (Oxford University Press, 2002), and The Six Principles of Managing with Integrity (Spiro Press, 2005). Muel is section-editor for the Journal of Business Ethics. 


\section{Developing and testing a measure for the ethical}

\section{culture of organizations:}

\section{the corporate ethical virtues model ${ }^{* \dagger}$}

Summary Based on four interlocking empirical studies, this paper initially validates and refines the Corporate Ethical Virtues Model which formulates normative criteria for the ethical culture of organizations. The findings of an exploratory factor analysis provide support for the existence of eight unidimensional subscales: clarity, congruency of supervisors, congruency of management, feasibility, supportability, transparency, discussability, and sanctionability. The findings of a confirmatory factor analysis show that the overall fit of the model is quite high. Evidence of convergent and discriminant validity is also found. The resulting 58 -item self-reporting questionnaire is a useful tool that can be used in future research and by managers in assessing the ethical culture of their organization.

\footnotetext{
*Keywords: (1) Ethics; (2) Culture; (3) Virtues; (4) Construct Development; (5) Factor Analysis

${ }^{\dagger}$ Classification: Research article
} 


\section{Introduction}

In business ethics literature, the ethical organizational context as perceived by employees is represented primarily by two constructs: ethical climate and ethical culture (Treviño \& Weaver, 2003). Ethical climate is usually defined as those aspects that determine what constitutes ethical conduct (Victor \& Cullen, 1988). Ethical culture is usually defined as those aspects that stimulate ethical conduct (Treviño \& Weaver, 2003).

Whereas the construct of ethical climate has been developed meticulously and tested extensively by its originators (Victor \& Cullen, 1987, 1988) and others (Arnaud \& Schminke, 2007; Peterson, 2002; Weber, 1995; Wimbush, Shepard, \& Markham, 1997), the construct of ethical culture is, despite its significance (Hoffman, 1986; Key, 1999; Paine, 1994; Treviño \& Youngblood, 1990), still underdeveloped. Treviño, Butterfield and McCabe (1998) were the first to develop and test a construct of the ethical culture of organizations. They used fourteen items: six items for the sanctions for ethical and unethical conduct, three items for role modeling of top management, three items for the implementation of an ethics code, and one item for whether ethical behavior is the norm in the organization. Based on a study sample of 318 alumni of two private colleges, their exploratory factor analysis resulted in one factor for all fourteen items. Because they included a small set of items, they proposed that "future research should refine the ethical culture measure to make it more applicable" (1998: 263).

As yet, no empirical study has been conducted in response to their call to refine the construct of an ethical organizational culture. This paper takes up the challenge. To this end, the Corporate Ethical Virtues Model (abbreviated as CEV Model) as 
developed by Kaptein $(1998,1999)$ is used as this is the only existing model that comprises multiple normative dimensions for the ethical culture of organizations. The CEV Model comprises seven virtues which should be embedded in the culture of organizations and which represents the ethical quality of the organizational culture. This model, however, has not been tested empirically. In this paper, we will, in multiple interlocking empirical studies, conduct an exploratory factor analysis followed by a confirmatory factor analysis to test the CEV Model and to develop a self-reporting questionnaire for measuring the ethical culture of organizations.

The paper is structured as follows. First, the assumptions underlying and the dimensions comprising the CEV Model will be briefly discussed. This is followed by an account of the methodology of this study, followed by the results. The paper ends with an overview of the conclusions, suggestions for future research, limitations of this research, and general, much needed, applications in practice.

\section{The Corporate Ethical Virtues Model}

The CEV Model is grounded mainly in Solomon's virtue-based theory of business ethics (1992a, 1992b, 1999, 2000, 2004). This theory holds that individual business people as well as business organizations should possess certain characteristics, i.e. virtues, in order to excel morally. Following Collier (1995), Kaptein (1998) posits that the virtuousness of a corporation can be determined by the extent to which the organizational culture stimulates employees to act ethically and prevents them from acting unethically. Corporate ethical virtues are the organizational conditions for ethical conduct; they reflect the capacity of an organization to stimulate ethical conduct of employees. To define these virtues, Kaptein conducted a qualitative analysis of 150 
actual cases that included a variety of types of unethical employee conduct that was (partly) caused by the organizational culture. The outcome of his analysis and categorization of the organizational factors that contributed to the unethical conduct of employees was seven virtues. This set of generic and procedural oriented virtues is applicable to any business organization. In this respect, it differs from the construct of ethical climate, which because of its content orientation, is much more situational dependent (cf. Heugens, Kaptein, \& Van Oosterhout, 2006) and, as for example operationalized by Victor and Cullen (1988), not generally applicable as normative model. For example, it is unclear whether a climate of independence, which is one of the five dimensions of ethical climate as found by Victor and Cullen (1988), is morally desirable or not.

Below, each of the seven virtues will be discussed briefly. The first two virtues especially relate to the self-regulating capacity of the organization, the next two virtues to the self-providing capacity of the organization, and the last three virtues to the selfcorrecting or self-cleansing capacity of the organization.

The organizational virtue of clarity. The first organizational virtue is clarity of normative expectations regarding conduct of employees. These expectations should be concrete, comprehensive, and understandable. The business setting confronts employees with ethical issues that differ from those encountered in other social settings. For example, Crane and Matten (2007), DeGeorge (1999), Donaldson and Dunfee (1999), and Velasquez (2002), list many ethical issues which are specific and unique to the business setting. Consequently, general moral intuitions may not be sufficient for employees to distinguish between ethical and unethical conduct in the workplace. Kaptein (1998) posits that the more employees are left to their own discretion and moral intuition without a guiding organizational frame of reference, the higher the risk of unethical conduct. This corresponds with the findings of Bird and Waters (1989), 
Jackson (2000), and Tyler and Blader (2005) who see vagueness and ambiguity of moral expectations as one of the main sources of unethical conduct within organizations. A further risk of vague or unclear normative expectations is that employees may hide behind their ignorance or deliberately keep themselves uninformed, which leaves much scope for excuses and rationalizations (Bovens, 1998). Therefore, the virtuous organization is clear about the ethical standards employees should uphold.

The organizational virtue of congruency. Organizations may well stipulate clear normative expectations to guide employee conduct, but if management behavior, as an important source of normativity within organizations (Ciulla, 1998; Schein, 1985; Treviño, Hartman, \& Brown, 2000), contradicts these expectations, employees are confronted with incongruent or inconsistent signals. However, if the behavior of management is consistent with the normative expectations of the organization, the message to employees to comply with these expectations is reinforced. Kaptein (1998) found many instances of unethical conduct by employees which were motivated by the example set by a supervisor, manager or board member engaging in unethical and prohibited conduct. This corresponds with the views of Hegarty and Sims (1978), Brown, Treviño and Harrison (2005), and Schminke, Ambrose and Neubaum (2005) who found that employees often emulate leaders' behavior and look to leaders for clues to proper conduct. Therefore, a second virtue can be distinguished, namely the organizational virtue of congruency, which is an essential characteristic of organizations committed to preventing unethical conduct and promoting ethical conduct among their members. This second organizational virtue amounts to the moral requirement that managers should visibly act in accordance with normative expectations.

The organizational virtue of feasibility. The third virtue in the CEV Model refers to the extent to which the organization creates conditions which enable employees to 
comply with normative expectations. If employees have little or no scope to realize their tasks and responsibilities, the risk of unethical conduct increases. More specifically, Kaptein (1998) found that unethical conduct occurred when employees lacked adequate or sufficient time, budgets, equipment, information, and authority to fulfill their responsibilities. For example, in keeping with the findings of Treviño (1986), people under great time pressure are less inclined to pay attention to the legitimate expectations and interests of others than those who have sufficient time at their disposal. Schweitzer, Ordóñez and Douma (2004) also convincingly show in their empirical study that excessively high targets stimulate unethical behavior. The third organizational virtue Kaptein therefore discerned is the requirement that employees' responsibilities are feasible.

The organizational virtue of supportability. The fourth organizational antecedent to (un)ethical conduct within organizations is the extent to which the organization creates support among employees to meet normative expectations. Following the views of Blanchard and Peale (1988), Boye and Jones (1997), Greenberg (1997), Hollinger and Clark (1983), and Skarlicki, Folger and Tesluk (1999), Kaptein (1998) also found that demotivated and dissatisfied staff is more likely to behave unethically. Employees who feel that they are not taken seriously or are not treated fairly might try to balance the scales of justice by deliberately causing damage to the organization. Mistrust and a hostile work environment makes it difficult, if not impossible, to comply with the ethical standards of the organization. Tyler and Blader (2005) empirically found that when employees are encouraged to identify with the values of their organization, they are intrinsically motivated to comply with the ethical standards of the organization. According to the CEV model, the organizational virtue of supportability represents the extent to which organizations support ethical conduct of employees. Supportability refers to the relative strength of an individual's identification with, involvement in and 
commitment to the normative expectations of the organization and the extent to which the organization stimulates this.

The organizational virtue of transparency. The fifth virtue in the CEV Model refers to transparency or visibility in the organization. Employees can only be held responsible if they know, or could have known, the consequences of their actions (Bovens, 1998). Employees who are hardly aware of the nature or seriousness of the consequences of their conduct are deprived of the opportunity to account for, modify or alter their conduct. This can lead to a situation where employees only focus on the action without regard for its consequences (Bovens, 1998). In organizations with a high level of visibility or transparency, employees will succeed in modifying or correcting their behavior or that of their co-workers, supervisors, or subordinates (Kaptein, 1998). Conversely, low visibility or transparency diminishes the control environment, which widens the scope for unethical conduct. Many studies emphasize the importance of transparency not only for its potential to expose unethical conduct but also for acting as a deterrent due to the perceived probability of getting caught (Cressey, 1953; Hollinger \& Clark, 1982, 1983; McCabe, Treviño, \& Butterfield, 1996). Some scholars (ZeyFerrell \& Ferrell, 1982) have indicated that peers, peer perceptions, and frequent contact with peer groups strongly influence ethical decision-making and behavior thanks to the feedback, overview, disclosure and the diminished room for misinterpretation and dishonesty that accompanies it. The organizational virtue of transparency is defined as the degree to which employee conduct and its consequences are perceptible to those who can act upon it, i.e. colleagues, supervisor, subordinates and the employee(s) concerned. In the CEV Model, transparency is broken down into a horizontal and vertical component. The vertical component refers to the extent to which managers are able to observe unethical conduct and its consequences of employees (top-down) and vice versa (bottom-up). The horizontal component refers to the extent to which 
employees are able to observe unethical conduct and its consequences among themselves.

The organizational virtue of discussability. Another factor that characterizes the virtuousness of an organization concerns the opportunity employees have to raise and discuss ethical issues. Kaptein (1998) identified many examples of unethical conduct by employees which were partly caused by an organizational culture with a low level of discussability or debatability. In such a closed culture, criticism is neither encouraged nor accepted. People figuratively close their ears and eyes to what they do not want to hear or see. Such a situation is often characterized by "negative information blockage" (Bishop, 1991) and a tendency to "kill the messenger" (Kirrane, 1990), "screen bad news" (Bovens, 1998) or "pay lip service" (Cooke, 1991). The opportunity to learn from others' (near) mistakes, transgressions and dilemmas is lost if employees are not given adequate scope to exchange, analyze and discuss their experiences. Bird and Waters (1989) also posit that the persistent avoidance of moral talk reinforces an amoral organizational culture. If moral issues are not openly spoken about, they go unnoticed and unacknowledged, which leads to higher moral stress and a decline of the moral authority of normative expectations. In an organization with a high degree of discussability, lack of clarity on certain normative expectations, moral dilemmas and unethical behavior (through peer reporting or whistle-blowing) can be discussed. Whistle-blowing is defined by Near and Miceli (1985: 4) as "the disclosure by organizational members (former or current) of illegal, immoral, or illegitimate practices under the control of their employers to persons within the organization that may be able to effect action." Peer reporting is a kind of upward control (Graham, 1986) or a form of lateral control (Treviño \& Victor, 1992). If employees are expected to report perceived transgressions, their work environment should be experienced as a secure place where moral issues can be raised without fear of being victimized. 
The organizational virtue of sanctionability. The seventh and final organizational virtue in the CEV Model is labeled as sanctionability. Kaptein (1998) found a range of examples of unethical conduct that were preceded by similar forms of unethical conduct that were tolerated or even encouraged, in turn creating the perception among perpetrators that their conduct would go unpunished or that it would even be appreciated by management. The absence of the enforcement of sanctions undermines the effectiveness of norms. Sanctions are an important behavioral stimulus and a relevant source of normativity (Falkenberg \& Herrenans, 1995). According to Cressey (1953) and Sutherland (1940; 1983), employees will steer clear of misbehavior if they expect it to be punished and if the severity of punishment outweighs the potential reward. When managers reward employees for unethical behavior or fail to punish them for engaging in such behavior, they send a clear message that unethical behavior is acceptable or desirable (Ball, Treviño, \& Sims, 1994). Sanctions are imposed not just for the sake of the perpetrator and victim, but also for the benefit of onlookers. As Treviño, Weaver, Gibson and Toffler (1999: 139) state: “...discipline for rule violators serves an important symbolic role in organizations - it reinforces standards, upholds the value of conformity to shared norms and maintains the perception that the organization is a just place where wrongdoers are held accountable for their actions." Furthermore, Kaptein also analyzed examples in which the failure to reward ethical conduct led to unethical conduct. A lack of recognition for ethical conduct diminishes the willingness of employees to act ethically. This empirical finding corresponds with Román and Munuera's (2005) finding that the more ethical conduct is rewarded the fewer violations people commit. Therefore, the seventh organizational virtue, the organizational virtue of sanctionability, refers to the likelihood of employees being punished for behaving unethically and rewarded for behaving ethically. 


\section{Methods and results of four empirical studies}

To date, the CEV Model has not been tested to determine whether these seven virtues are unique dimensions or whether there is just one unilateral factor for the ethical culture as found by Treviño, Butterfield and McCabe (1998). In this section, the methods and results of four interlocking empirical studies are presented to validate the model and to develop a self-reporting questionnaire.

Study 1: Item generation

\section{Methods}

The overall aim of the research was to construct a scale so that (a) the items were simple (i.e. reflecting a single construct), and relatively neutral in wording; and (b) it was fairly brief, thus reducing the potential respondent burden (Podsakoff, MacKenzie, \& Lee, 2003; Tourangeau, Rips, \& Rasinksi, 2000). Existing theory and empirical research (Ethics Resource Center, 2003; Kaptein \& Van Dalen, 2000; Treviño \& Weaver, 2003) was drawn upon to generate a set of 96 items for the questionnaire. The initial set of items was revised on the basis of feedback from 10 academic experts in business ethics, organizational behavior and the development of questionnaires; 50 practitioners (managers, employees and ethics officers from 10 different organizations); and 15 management consultants in the field of international business ethics and integrity. ${ }^{1}$ All items were rated for clarity using a six point scale ranging from " $1=$ Very Unclear" to "6=Very Clear". Participants also had to provide their interpretation of every question as well as suggestions for improvement. The questionnaire was then pre-tested using a convenience sample of 24 business students, and 621 managers and employees. All 
items were followed by a six-point Likert-type response scale ranging from " $1=$ Strongly Disagree" to "6=Strongly Agree".

\section{Results}

Based on an analysis of the results of this pilot, 23 items were eliminated on the basis of item complexity, low levels of variance, and high levels of skewedness and kurtosis. The remaining 72 items were used to compile the questionnaire that was used in the second study. Most questions pertain to the direct working environment of the respondents rather than the organization as a whole. This direct working environment was defined as the team, group or department one functions in. By limiting the scope, the validity of the answers might be enhanced as respondents have the most concrete experiences within their team. Furthermore, it makes it possible to compare sub-units within one organization.

Clarity. The clarity of organizational norms consisted of 11 items. Nine questions were related to whether the organization makes it sufficiently clear to the respondents how they should conduct themselves with respect to (a) colleagues, (b) authorizations, (c) company equipment, (d) working hours, (e) money and other financial assets, (f) sideline activities, (g) confidential information, (h) actions toward external persons and organizations, and (i) the natural environment. Two additional questions were formulated in more general terms regarding the clarity of communication regarding (j) the manner in which employees should conduct themselves and $(\mathrm{k})$ the applicable values and norms.

Congruency. The organization's consistency was measured by means of ten items reflecting the respondent's perception of the extent to which board, (senior) management and their supervisor set a good example in terms of ethics. 
Feasibility. The feasibility dimension refers to the extent to which employees are enabled to act ethically. It was measured by means of seven items regarding the extent to which respondents have enough time, means and information at their disposal to act ethical responsibly (three items) and whether they are put under pressure to act irresponsibly and to contravene ethical standards (four items).

Supportability. The virtue of supportability consisted of nine items. The items concerned the extent to which respondents experience trust and respect in their working environment and the extent to which employees identify and endorse the values, norms and rules of the organization.

Transparency. The transparency of the working environment included ten items. The items concerned the extent to which respondents' actions are visible to themselves and their colleagues and managers. The list also included items regarding the extent to which unethical conduct of one's supervisor becomes visible as well as the extent to which respondents receive feedback on the criticism they give on the behavior of others.

Discussability. The virtue of discussability refers to the extent to which ethical issues can be openly discussed in the organization. It was measured with reference to thirteen items related to the scope for discussion of ethical dilemmas and unethical conduct with colleagues, supervisor or someone else in the organization.

Sanctionability. The organizational virtue of sanctionability contained twelve items regarding the punishment of unethical conduct and reward and recognition of ethical conduct.

Study 2: Exploratory factor analysis

\section{Methods}


Factor analysis is a statistical technique used to identify a relatively small number of factors that can be used to represent relationships among sets of many interrelated variables. Its primary objective is data reduction and summarization with a minimum loss of information (Babbie, 1992; Hair, Anderson, Tatham, \& Black 1995; Kim \& Mueller, 1978). This research was the first empirical validation study of the seven proposed ethical virtues thus warranting a careful investigation of its properties. To this end, the items of Study 1 were subjected to an exploratory factor analysis. Whereas Treviño, Butterfield, and McCabe (1998) performed a principal component analysis with varimax rotation, Fabrigar et al. (1999) note that principal component analysis should not be used as a substitute for exploratory factor analysis. As recommend by Fabrigar et al. (1999), in this study, a principal axis factoring with an oblique rotation (direct) oblimin was used, allowing for correlations among factors. The reduced-scale items were then included in a confirmatory factor analysis in Study 3.

The sample for the exploratory study was drawn from a Dutch organization with 382 employees. All employees received a cover letter and a questionnaire in Dutch measuring their perception of the 72 items of the ethical culture of their organization. ${ }^{2}$ Respondents were provided with franked envelops to return the questionnaires to the author. Completion of the survey was completely voluntary and anonymous. 242 completed surveys were returned which amounted to a response rate of $63.5 \%$. The majority of the sample members were male (55\%). The average position tenure was 11 years $(\mathrm{SD}=7.0)$, with a mean age of 39 years. The overall quality of the data in terms of completeness was adequate. The respondents answered the majority of the items: all 72 items had a missing data rate below 5\%. 


\section{Results}

The exploratory factor analysis revealed 8 factors with eigenvalues greater than one. Based on parallel analysis relative to random data eigenvalues (Montanelli \& Humphreys, 1976; Fabrigar, Wegener, MacCallum, \& Strahan, 1999), a steep break in the eigenvalues plot between the eighth and ninth factor (eigenvalues of 1.42 and 0.97 ) also indicated an eight-factor solution. Within these factors, individual items were retained if their loading was greater than 0.4 . Items were eliminated if an item's loading was 0.30 or greater for more than one factor. In total, 58 items were extracted.

The initial eigenvalues of these factors are $23.50,4.68,3.43,2.56,2.01,1.75$, 1.59, and 1.42. The variance accounted for by these factors is respectively $39.84,7.93$, $5.81,4.33,3.40,2.97,2.69$, and 2.41 for a proportion of 69.38 of the total variance. Table 1 shows the 8 extracted factors after conducting the varimax rotation, including items, factor loadings, personal eigenvalues and explained variances. The 8 factors correspond with the 7 corporate ethical virtues as identified by Kaptein with only one exception. The virtue of congruency falls into two distinctive categories: role modeling of management and role modeling of supervisors. Supervisors are defined as the direct manager of the respondents, management is defined as all managerial levels higher than the supervisor.

Insert Table 1 about here 
Study 3: Confirmatory factor analysis

\section{Methods}

The remaining items from Study 2 were subjected to a confirmatory factor analysis. The sample for the confirmatory study was composed from another organization in the Netherlands. All 725 employees were mailed a cover letter, a questionnaire in Dutch and a franked envelop. Completion of the survey was completely voluntary and anonymous. 312 completed surveys were returned which amounts to a response rate of $43 \%$. The average position tenure was 8.1 years $(\mathrm{SD}=5.99)$ and $49 \%$ was male. The overall quality of the data in terms of completeness was adequate: all 58 items had a missing data rate below $5 \%$.

Confirmatory factor analysis was conducted to assess the goodness-of-fit of the latent structure underlying the ethical culture indicators. Structural equation modeling was used for parameter estimation and for model testing. The hypothetical model has been estimated by least squares using the CALIS procedure of SAS. Several fit measures were used. The goodness-of-fit index (GFI), as developed by Jöreskog and Sörbom (1985; 1993), indicates how well the observed covariance matrix of the analyzed items is reproduced by the estimated covariance matrix. Values larger than 0.9 are required for good-fitting models. As the GFI is sensitive to the number of estimated parameters, alternatives have been proposed such as the Adjusted GFI (AGFI) and the parsimonious GFI (PGFI) by James, Mulaik and Brett (1982), which correct the GFI by taking into account the number of parameters estimated and degrees of freedom. Other measures of fit, which are used by $\mathrm{Hu}$ and Bentler (1999) and Maiti and Mukherjee (1990), are the root of the mean of the squared residuals (differences between the observed and estimated correlations; RMSR), and the root mean square error of approximation (a measure of the discrepancy per degree of freedom; RMSEA), which 
should have values no larger than 0.06. Bentler's (1990) comparative fit index (CFI), which relates the (lack of) fit of the estimated model to that of a null model (the same model, but with covariances set equal to zero), is sometimes preferred to indicate goodness-of-fit ( $c f$. Medsker, Williams, \& Holahan, 1994). The proposed index, which Bentler termed delta statistic (б), should have a recommended value of at least 0.90 to have confidence in the model fit. The chi-square statistic $\left(\chi^{2}\right)$ and its associated $p$-value are used to evaluate the assumption that the reproduced correlation matrix perfectly matches the observed correlation matrix. The $\chi^{2}$ statistic formally tests the null and alternative hypotheses where the null hypothesis refers to a hypothesized model that fits the data and the alternative hypothesis refers to some other model that fits the data. A significant $\chi^{2}$ statistic indicates a misfit between the model and the sample data. An insignificant $\chi^{2}$ statistic indicates that the model and the sample data are consistent. It is well known that the $\chi^{2}$ statistic is highly sensitive to the sample size (Anderson and Gerbing, 1984). For a large sample size, a small difference between the sample covariance matrix and the estimated covariance matrix will produce a statistically significant $\chi^{2}$ statistic, thereby rejecting the model. In the present study, more emphasis was therefore put on the previously discussed fit measures.

The discriminant and convergent validity of the eight ethical culture dimensions was further analyzed by a second-order confirmatory factor analysis in which each of the dimensions was assumed to originate from an encompassing construct of the ethical organizational culture (see, for example, Gerbing, Hamilton, and Freeman (1994); Jarvis, MacKenzie, and Podsakoff (2003); Spreitzer (1995); Spreitzer, Kizilos, and Nason (1997)). The objective of this analysis was to establish whether the eight dimensions can indeed be interpreted as distinct dimensions of the ethical organizational culture (discriminant validity) and whether the relation between the overall ethical 
organizational culture and each of the separate dimensions is positive as it should be according to the model assumptions (convergent validity).

\section{Results}

All factor loadings were highly significant, and fit indicators denoted a high degree of fit. Table 2 provides the results.

Clarity. Clarity is measured by means of 10 items. Its internal consistency $(\alpha)$ is 0.93 and the goodness-of-fit of the underlying model is good $\left(\chi^{2}=75.00, \mathrm{DF}=9\right.$, $\mathrm{GFI}=0.99, \mathrm{AGFI}=0.99, \mathrm{PGFI}=0.77, \mathrm{RMSR}=0.05, \mathrm{RMSEA}=0.00$, and $\mathrm{CFI}=0.95)$.

Congruency of supervisors. The congruency of supervisors, measured by means of 6 items, has an internal consistency of 0.95 . The goodness-of-fit of the underlying model is $\operatorname{good}\left(\chi^{2}=181.68, \mathrm{DF}=9, \mathrm{GFI}=0.99, \mathrm{AGFI}=0.99, \mathrm{PGFI}=0.60, \mathrm{RMSR}=0.04\right.$, RMSEA $=0.00$, and CFI $=0.89$ ).

Congruency of management. The internal consistency $(\alpha)$ of the 4-item factor congruency of management is 0.95 and the goodness-of-fit of the underlying model is also $\operatorname{good}\left(\chi^{2}=4.73, \quad \mathrm{DF}=2, \quad \mathrm{GFI}=0.99, \quad \mathrm{AGFI}=0.99, \quad\right.$ PGFI $=0.33, \quad \mathrm{RMSR}=0.01$, RMSEA $=0.00$, and CFI $=0.99$ ).

Feasibility. Feasibility is measured by means of 6 items. The internal consistency $(\alpha)$ of this factor is 0.96 . The goodness-of-fit is also $\operatorname{good}\left(\chi^{2}=59.76, \mathrm{DF}=9\right.$, $\mathrm{GFI}=0.99, \mathrm{AGFI}=0.99, \mathrm{PGFI}=0.60, \mathrm{RMSR}=0.02, \mathrm{RMSEA}=0.00$, and $\mathrm{CFI}=0.97)$.

Supportability. The internal consistency $(\alpha)$ of this 6-item indicator for supportability amounts to 0.95 , while the goodness-of-fit indicators suggest a good performance of the measurement model $\left(\chi^{2}=28.19, \mathrm{DF}=9, \mathrm{GFI}=0.99, \mathrm{AGFI}=0.99\right.$, PGFI $=0.60$, RMSR $=0.01$, RMSEA $=0.00$, and $\mathrm{CFI}=0.99)$. 
Transparency. The internal consistency $(\alpha)$ of the resulting 7-item scale of transparency is 0.93 . The goodness-of-fit of the model is again good $\left(\chi^{2}=92.71, \mathrm{DF}=14\right.$, $\mathrm{GFI}=0.99, \mathrm{AGFI}=0.99, \mathrm{PGFI}=0.66, \mathrm{RMSR}=0.04, \mathrm{RMSEA}=0.00$, and $\mathrm{CFI}=0.94)$.

Discussability. The factor of discussability is measured by means of 10 items. The internal consistency $(\alpha)$ is 0.94 and the goodness-of-fit of the measurement model is again $\operatorname{good}\left(\chi^{2}=282.65, \mathrm{DF}=35, \mathrm{GFI}=0.99, \mathrm{AGFI}=0.99, \mathrm{PGFI}=0.77 \mathrm{RMSR}=0.04\right.$, RMSEA $=0.01$, and $\mathrm{CFI}=0.92$ ).

Sanctionability. The internal consistency $(\alpha)$ of the 9-item factor of sanctionability is 0.94 and the goodness-of-fit of the underlying model is good $\left(\chi^{2}=202.97, \mathrm{DF}=27, \mathrm{GFI}=0.99, \mathrm{AGFI}=0.98, \mathrm{PGFI}=0.75, \mathrm{RMSR}=0.04, \mathrm{RMSEA}=0.00\right.$, and $\mathrm{CFI}=0.94)$.

Insert Table 2 about here

The results of the second-order confirmatory factor analysis are summarized in Figure 1. The overall fit of the model is $\operatorname{good}(\mathrm{GFI}=0.98, \mathrm{AGFI}=0.98, \mathrm{PGFI}=0.94$, RMSR $=0.06$, RMSEA $=0.01$, and $\mathrm{CFI}=0.93$ ). All observed items load positively and significantly on the postulated dimensions (discriminant validity), while in turn these dimensions load positively on the overall ethical organizational culture (convergent validity). Thus, the CFA-results provide support for the assumed CEV Model. 


\section{Insert Figure 1 about here}

Study 4: Multivariate analyses of variance

\section{Methods}

To address the question of whether organizations have identifiable ethical organizational cultures, multivariate analyses of variance were conducted on a sample of employees from three other companies in the Netherlands: an electronics retail store, a security company, and a waterworks. In all three companies, completion of the survey was completely voluntary and anonymous. Because the official language of all three companies was Dutch, the questionnaires were also in Dutch. The response rates of usable questionnaires were respectively $65 \%(\mathrm{~N}=57), 52 \%(\mathrm{~N}=66)$, and $51 \%(\mathrm{~N}=112)$, for a total of 235 questionnaires. The mean percentage of men and years of working at the organization were respectively $69 \%$ and $5.8(\mathrm{SD}=5.4), 62 \%$ and $6.5(\mathrm{SD} .=7.5)$, and $75 \%$ and $6.7(\mathrm{SD}=7.5)$. The James, Demaree, and Wolf (1993) within-group agreement index (Rwg) was used to assess whether the aggregation of data justified higher levels of analysis.

\section{Results}

Table 3 shows the results for the Rwg. Only the Rwg for congruency of management is below the minimum level of 0.7 . The average Rwg score of 0.65 is caused by a very low Rwg of 0.41 at the Electronics Retail Store, whereas for the two other companies the Rwg for congruency of management is above 0.7. Additional interviews with respondents of the Electronics Retail Store showed that the store's employees had no 
contact with the board and senior management of their company as top management is located in another city, creating very diverging and vague views on the function of management as role model.

\section{Insert Table 3 about here}

Table 4 depicts the results of the multivariate analysis of variance by company. The results indicate a significant overall difference between the three companies on the dimensions of their ethical organizational culture $(\mathrm{F}=6.68, \mathrm{p}<.001)$. The Electronics Retail Store shows, with an average score of 4.6, the best ethical culture. Except for the virtue of sanctionability, respondents are more positive about the presence of the corporate ethical virtues in their organization than in the two other companies. The virtue of sanctionability is valued most highly by the respondents of Waterworks. Five virtues are more positively evaluated in Waterworks than in the Security Company. The Security Company scores slightly better than Waterworks on the virtues of clarity and congruency of management.

Univariate analyses of variance revealed significant differences on four dimensions; i.e. clarity, congruency of management, supportability, and transparency. The greatest contrasts were between supportability $(0.7$ between the Electronics Retail Store and the Security Company) and transparency (also 0.7 between the Electronics Retail Store and the Security Company). The data show that these four ethical virtues are sufficiently strong and identifiably different to produce significant discrimination among the companies. Three other dimensions, i.e. feasibility, discussability and 
sanctionability, are almost significant, with alphas between 0.07 and 0.05 . Congruency of supervisors is clearly non-discriminant.

Insert Table 4 about here

\section{Discussion}

The Corporate Ethical Virtues Model as developed by Kaptein (1998, 1999), formulates normative criteria for the ethical culture of organizations. This paper has taken the first steps towards validating and refining the model. An exploratory factor analysis provided support for the existence of eight unidimensional corporate ethical virtues: clarity, congruency of supervisors, congruency of management, feasibility, supportability, transparency, discussability, and sanctionability. Item reliabilities ranged between 0.93 and 0.96 and tests produced strong evidence supporting the convergent and discriminant validity of the structure of the ethical organizational culture. A confirmatory factor analysis indicated that items loaded only onto their respective latent variables, thus demonstrating the unidimensionality of each corporate ethical virtue. Multivariate analyses of variance between three companies revealed significant or almost significant differences on all the eight virtues except for the virtue of congruency of supervisors. 
Implications for future research

The development of valid and reliable measures is essential for improving business ethics theory and research. In their preliminary research, Treviño, Butterfield and McCabe (1998) found one factor of fourteen items for the ethical organizational culture. They also recommended follow-up research to validate their findings and look for the possibilities to refine their construct. This paper took up this challenge. The eight subscales that have been distinguished and the resulting 58-item self-reporting questionnaire allow us to measure and understand the ethical culture of organizations better, thus opening at least three promising directions for future research.

A first direction relates to measuring and comparing the ethical culture of organizations. Many studies have been conducted to compare the culture of different organizations (cf. Hofstede et al., 1990). The questionnaire developed in this study can be used to examine the extent to which the ethical culture of organizations differs. Such future research could also reveal to what extent the eight ethical virtues differ by function, hierarchical level, sector, and nation, which can help us to achieve a better understanding of the multifaceted construct of ethical organizational culture.

A second direction for future research relates to analyzing the impact of the different dimension of the ethical culture on different types of ethical and unethical conduct. Ethical culture in this paper has been defined as the perceived conditions in the organizational context that stimulate employees to behave ethically. The developed and tested questionnaire can be used to assess the impact of ethical culture on ethical and unethical conduct and to find out to what extent the different virtues have a different impact on different types of conduct ( $c f$. Peterson, 2002). For example, low feasibility may have a greater impact on the frequency of fraud than on the number of employees that engage in conflicting sideline activities. Or the virtue of discussability may have a 
greater impact on the occurrence of that type of misconduct that is more difficult to define clearly in advance (such as intrapersonal misbehavior as intimidation, harassment and bullying) than misconduct that can be formulated in clear prohibitions (such as when business equipment may be used for private purposes). The results of this study show that the role model function of managers and supervisors are two different dimensions. This implies that in order to understand and use the role of management in an organization, these two dimensions should be taken into account since each may have a different impact on the scale of unethical conduct of employees.

A third fruitful direction for future research is related to studying the effectiveness of ethics measures, such as a written code of ethics (Stevens et al., 2005), ethics training programs (Delaney \& Sockell, 1992), and ethics helplines or whistleblower schemes (Near \& Miceli, 1995). It is not only the question to what extent ethical cultures differ, what the relationships are between the constitutive virtues of the ethical organizational culture and the impact of these virtues on ethical and unethical conduct, but also how different measures can have a different impact on the different virtues. For example, a code of ethics may be more effective in increasing clarity than in increasing achievability, because a code clarifies what ethical conduct is expected and does not necessarily provide employees with the means to realize their responsibilities. And ethics helplines probably mainly affect the virtue of discussability as they provide a structure for reporting violations and sharing ethical dilemmas ( $c f$. Near \& Miceli, 1995).

\section{Limitations of this research}

Although this study makes several contributions, it also has several limitations. Four limitations will be discussed here. 
A first limitation relates to the number of samples used in the paper as well as the language in which the survey was conducted. While Study 1 was conducted using participants from different countries and continents, all three other studies were conducted in the Netherlands. While much attention has been paid to carefully translate the questionnaire into Dutch, the possibility of measurement nonequivalence across languages and national cultures has to be acknowledged. Further testing in other countries and continents is needed to further assess the robustness of the eight dimensions of the ethical organizational culture as found in this research project.

A second limitation relates to the limited research into the convergent and discriminant validity of the new construct of the ethical organizational culture that has been developed in this paper. In this study the developed multidimensional measure for ethical culture was not correlated with measures used in the same field of research, such as Treviño, Butterfield and McCabe's (1998) first and only one-dimensional measure of ethical culture. Neither has there been an assessment of the relationship with measures of unrelated constructs or closely related constructs, such as ethical climate (Victor and Cullen, 1988) and organizational cultural in general (such as Hofstede's (1980) five dimensional model). Treviño, Butterfield and McCabe (1998) found that ethical climate had a higher variance in explaining unethical conduct than ethical culture. However, as their conception of ethical culture is one-dimensional, a more elaborate assessment of ethical culture could generate different results. More research is therefore required to support the convergent and discriminant validity of the measure developed in this paper.

A third limitation concerns some less significant findings in this paper. Study 4 showed significant differences between three companies on only four corporate ethical virtues (i.e. an alpha lower than 0.05). Although three other virtues had an alpha not higher than 0.07 , these results are not convincing. Perhaps a more diverse group of participating companies would have led to significant results. Future research into 
companies in, for example, different countries is therefore needed. Because the withingroup agreement index (Rwg) of the virtue of congruency of management was not significant at one company in Study 4, it is also necessary to find out what precludes or facilitates aggregating the data for higher levels of analysis. For now, additional interviews showed that a lack of familiarity with board and management resulted in very different and vague perceptions of their function as role model among respondents.

A fourth limitation of this paper is that in operationalizing the ethical culture of an organization, only the model of Kaptein (1998) has been used. Although the research of Kaptein shows no indications of incompleteness, the question still remains whether this model contains all relevant dimensions of the ethical culture of an organization. For example, Murphy (1999), Nash (1990), Shanahan and Hyman (2003), Solomon (1999), and Spears (1998) propose different sets of virtues, although these sets are substantive (i.e. more climate related) and organization specific instead of procedural and generic. Although it falls beyond the scope of this article to establish the comprehensiveness of this model, the questionnaire can be used in future research to ascertain the extent to which this model explains the total impact of the organizational culture on unethical and ethical conduct. By simultaneously also measuring other antecedents for ethical and unethical conduct, such as factors outside the organization (Baucus \& Near, 1991) and personal characteristics of employees (Treviño \& Youngblood, 1990), the comparative impact of the ethical organizational culture on the ethical and unethical conduct of employees can be determined.

\section{Practical implications}

The partly validated CEV Model and the accompanying questionnaire can be used by practitioners to examine and measure the ethical quality of the working environment. 
Due to new regulations in the field of corporate governance, such as the US SarbanesOxley Act, companies listed on the stock exchange are required to monitor their control environment. The ethical culture of the organization forms part of this environment (Green, 2004). The CEV Model provides a framework to examine the ethical culture of organizations; the resulting questionnaire is an instrument to measure it among managers and employees. On the basis of the results of such an internal assessment, management can determine the extent to which they are in control, understand the causes and antecedents of unethical conduct within the organization and decide where additional measures are required. If the response per organizational unit is sufficient, comparisons can be made and even more tailored actions can be taken. By measuring the perceived ethics of organizations in a valid and sophisticated manner, ethics can be managed more effectively. 


\section{References}

Anderson, J.C., \& Gerbing, D.W. (1984). The effect of sampling error on convergence, improper solutions, and goodness-of-fit indices for maximum likelihood confirmatory factor analysis, Psychometrika, 49, 155-173.

Arnaud, A.U., \& Schminke, M. (2007). Beyond the organizational bases of ethical work climates: a new theory and measure. Administrative Science Quarterly, 33: 101125.

Babbie, E. (1992). The Practice of Social Research. Belmont, CA: Wadsworth Publishing.

Ball, G.A., Treviño, L.K., \& Sims Jr., H.P. (1994). Just and unjust punishment: Influences on subordinate performance and citizenship. Academy of Management Journal, 37, 299-322.

Baucus, M.S., \& Near, J.P. (1991). Can illegal corporate behavior be predicted? An event history analysis. Academy of Management Journal, 34, 9-36.

Bentler, P.M. (1989). Theory and Implementation of EQS: A structural equations program. Manual for program version 2.0. Los Angeles: BMDP.

Bird, F.B. (1996). The Muted Conscience: Moral silence and the practice of ethics in business. Westport: Quorum Books.

Bird, F.B., \& Waters, J.A. (1989). The moral muteness of managers. California Management Review, 32, 73-88.

Bishop, J.D. (1991). The moral responsibility of corporate executives for disasters. Journal of Business Ethics, 10, 377-83.

Blanchard, K., \& Peale, N.V. (1988). The Power of Ethical Management: Why the ethical way is the profitable way in your life and in your business. New York: Morrow. 
Bovens, M. (1998). The Quest for Responsibility: Accountability and citizenship in complex organizations. Cambridge: Cambridge University Press.

Boye, M.W., \& Jones, J.W. (1997). Organizational culture and employee productivity. In R.A. Giacalone \& J. Greenberg (Eds.), Antisocial Behavior in Organizations (pp. 172-84). Sage: Thousand Oaks.

Brown, M.E., Treviño, L.K., \& Harrison, D.A. (2005). Ethical leadership: A social learning perspective for construct development and testing. Organizational Behavior and Human Decision Processes, 97, 117-34.

Castro, S.L. (2002). Data analytic methods for the analysis of multilevel questions: A comparison of intraclass correlation coefficients, $r w g(j)$, hierarchical linear modeling, within- and between-analysis, and random group resampling. Leadership Quarterly, 13, 69-93.

Crane, A., \& Matten, D. (2007). Business Ethics. Oxford: Oxford University Press.

Ciulla, J.B. (Ed.) (1998). Ethics: The heart of leadership. Westport: Preager.

Collier, J. (1995). Business ethics research: Shaping the agenda. Business Ethics: A European Review, 4, 6-12.

Cooke, R.A. (1991). Danger signs of unethical behavior: How to determine if your firm is at ethical risk. Journal of Business Ethics, 10, 249-53.

Cressey, D.R. (1953). Other People's Money: A study in the social psychology of embezzlement. New York: Free Press.

DeGeorge, R.T. (1999). Business Ethics. New York: Prentice Hall.

Delaney, J.T., \& Sockell, D. (1992). Do company ethics training make a difference? An empirical analysis. Journal of Business Ethics, 11, 719-727.

Donaldson, T., \& Dunfee, T.W. (1999). Ties that Bind: A social contracts approach to business ethics. Boston: Harvard Business School Press. 
Ethics Resource Center (2003). National Business Ethics Survey 2003. Washington: ERC.

Falkenberg, L., \& Herrenans, I. (1995). Ethical behaviors in organizations directed by the formal or informal systems. Journal of Business Ethics, 14, 133-43.

Fabrigar, L.R., Wegener, D.T., MacCallum, R.C., \& Strahan, E.J. (1999). Evaluating of the use of exploratory factor analysis in psychological research. Psychological Methods, 4, 272-99.

Gerbing, D.W., Hamilton, J.G., \& Freeman, E.B. (1994). A large-scale second-order structural equations model of the influence of management participation on organizational planning benefits. Journal of Management, 20, 859-85.

Graham, J.W. (1986). Principled organizational dissent: A theoretical essay. In L.L. Cummings \& B. M. Staws (Eds.), Research in Organizational Behavior (Volume 8, pp. 1-52). Greenwich: JAI Press.

Green, S. (2004). Manager's Guide to the Sarbanes-Oxley Act. Hoboken: John Wiley \& Sons.

Greenberg, J. (1997). The STEAL motive: Managing the social determinants of employee theft. In R.A. Giacalone \& J. Greenberg, Antisocial Behavior in Organizations (pp. 85-108), Thousand Oaks: Sage.

Hair, J.F., Anderson, R.E., Tatham, R.L., \& Black, W.C. (1995). Multivariate Data Analysis: With readings. New York: Prentice-Hall.

Harkness, J.A., \& Schoua-Glusberg, A. (1998). Questionnaires in translation. ZUMANachrichten Spezial, 7, 87-125.

Hegarty, W.H., \& Sims, H.P. (1978). Some determinants of unethical decision behavior: An experiment. Journal of Applied Behavior, 63, 451-57. 
Heugens, P.P.M.A.R., Kaptein, M., \& Van Oosterhout, J. (2006). The ethics of the node versus the ethics of the dyad? Reconciling virtue ethics and contractualism. Organization Studies, 27, 391-411.

Hoffman, W.M., \& Moore, J.M. (1990). Business Ethics: Readings and cases in corporate morality. New York: McGraw-Hill.

Hofstede, G. (1980). Culture's Consequences: International differences in work-related values. London: Sage.

Hofstede, G., Neuijen, B., Ohayv, D.D., \& Sanders, G. (1990). Measuring organizational cultures: A qualitative and quantitative study across twenty cases. Administrative Science Quarterly, 35, 286-316.

Hollinger, R.C., \& Clark, J.P. (1982). Formal and informal social controls of employee deviance. Sociological Quarterly, 23, 333-43.

Hollinger, R.C., \& Clark, J. (1983). Deterrence in the workplace: Perceived certainty, perceived severity and employee theft. Social Forces, 62, 398-418.

Hu, L., \& Bentler, P.M. (1999). Cutoff criteria for fit indexes in covariance structure analysis: Conventional criteria versus new alternatives. Structural Equation Modeling, 6, 1-55.

Jackson, T. (2000). Management ethics and corporate policy: A cross-cultural comparison. Journal of Management Studies, 37, 349-69.

James, L.R, Mulaik, S.A., \& Brett, J.M. (1982). Causal Analysis. Beverly Hills: Sage Publications.

James, L.R., Demaree, R.G., \& Wolf, G. (1993). Rwg: An assessment of within-group interrater agreement. Journal of Applied Psychology, 78: 306-309.

Jarvis, C.B., MacKenzie, S.B., \& Podsakoff, P.M. (2003). A critical review of construct indicators and measurement model misspecification in marketing and consumer research. Journal of Consumer Research, 30, 199-218. 
Jöreskog, K.G., \& Sörbom, D. (1985). LISREL 6: Analysis of linear structural relationships by maximum likelihood, instrumental variables, and least squares. Uppsala: University of Uppsala.

Jöreskog, K.G., \& Sörbom, D. (1993). LISREL 8: Structural equation modeling with the SIMPLIS command language. Hillsdale: Erlbaum.

Kaptein, M. (1998). Ethics Management: Auditing and developing the ethical content of organizations. Dordrecht: Springer.

Kaptein, M. (1999). Integrity management. European Management Journal, 17, 625-34.

Kaptein, M., \& Dalen, van J. (2000). The empirical assessment of corporate ethics: a case study. Journal of Business Ethics, 24, 95-114.

Kaptein, M., \& Wempe, J. (2002). The Balanced Company: A theory of corporate integrity. Oxford: Oxford University Press.

Key, S. (1999). Organizational ethical culture: Real or imagined? Journal of Business Ethics, 20, 217-225.

Kim, J., \& Mueller, C.W. (1978). Factor Analysis: Statistical methods and practical issues. Newsbury Park: Sage Publications.

Kirrane, D.E. (1990). Managing values: A systematic approach to business ethics. Training \& Development Journal, 44, 11, 53-60.

Maiti, S.S., \& Mukherjee, B.N. (1990). A note on the distributional properties of the Jöreskog-Sörbom fit indices. Psychometrika, 55, 721-26

McCabe, D, Treviño, L.K., \& Butterfield, K. (1996). The influence of collegiate and corporate codes on conduct on ethics-related behavior in the workplace. Business Ethics Quarterly, 6, 441-60.

Medsker, G.J., Williams, L.J., \& Holahan, P.J. (1994). A review of current practices for evaluating causal models in organization behavior and human resources management research. Journal of Management, 20, 439-64. 
Montanelli, R.G., \& Humphreys, L.G. (1976). Latent roots of random data correlation matrices with squared multiple correlations on the diagonal: A Monte Carlo study. Psychometrika, 41, 341-48.

Murphy, P.E. (1999). Character and virtue ethics in international marketing: An agenda for managers, researchers and educators. Journal of Business Ethics, 18, 107-25.

Nash, L.L. (1990). Good Intentions Aside: A managers guide to resolving ethical problems. Boston: Harvard Business School Press.

Near, J.P., \& Miceli, M.P. (1985). Organizational dissidence: The case of whistleblowing. Journal of Business Ethics, 4, 1-16.

Near, J.P., \& Miceli, M.P. (1995). Effective whistle-blowing. Academy of Management Review, 20, 679-708.

Paine, L.S. (1994). Managing for organizational integrity. Harvard Business Review, $72,2,106-17$.

Peterson, D.K. (2002). The relationship between unethical behavior and the dimensions of the ethical climate questionnaire. Journal of Business Ethics, 41, 313-326.

Podsakoff, P.M., MacKenzie, S.B., \& Lee, J.Y. (2003). Common method variance in behavioral research: a critical review of the literature and recommended remedies. Journal of Applied Psychology, 88, 879-903.

Román, S., \& Munuera, J.L. (2005). Determinants and consequences of ethical behaviour: an empirical study of salespeople. European Journal of Marketing, $39,473-95$.

Schein, E. (1985). Organizational Culture and Leadership. San Francisco: Jossey-Bass.

Schminke, M., Ambrose, M.L., \& Neubaum, D.O. (2005). The effect of leader moral development on ethical climate and employee attitudes. Organizational Behavior and Human Decision Processes, 97, 135-51. 
Schweitzer, M.E., Ordóñez, L., \& Douma, B. (2004). Goal setting as a motivator of unethical behavior. Academy of Management Journal, 47, 422-32.

Shanahan, K.J., \& Hyman, M.R. (2003). The development of a virtue ethics scale. Journal of Business Ethics, 42, 197-208.

Sims, R.R., \& Brinkmann, J. (2002). Leaders as moral role models: The case of John Gutfreund at Salomon Brothers. Journal of Business Ethics, 35, 327-39.

Skarlicki, D.P., Folger, R., \& Tesluk, P. (1999). Personality as a moderator in the relationship between fairness and retaliation. Academy of Management Journal, 42, 100-08.

Solomon, R.C. (1992). Ethics and Excellence. New York: Oxford University Press.

Solomon, R.C. (1999). A Better Way to Think about Business: How personal integrity leads to corporate success. New York: Oxford University Press.

Solomon, R.C. (2000). Business with virtue: Maybe next year. Business Ethics Quarterly, 10, 319-31.

Solomon, R.C. (2004). Aristotle, ethics and business organizations. Organization Studies, 25, 1021-43.

Spears, L. (1998). Insights on Leadership. New York: Wiley.

Spreitzer, G.M. (1995). Psychological empowerment in the workplace: dimensions, measurement, and validation. Academy of Management Journal, 38, 1442-65.

Spreitzer, G.M., Kizilos, M.A., \& Nason, S.W. (1997). A dimensional analysis of the relationship between psychological empowerment and effectiveness, satisfaction, and strain. Journal of Management, 23, 679-704.

Stevens, J., Steensma, H., Harrison, D., \& Cochran, P. (2005). Symbolic or substantive document? The influence of ethics codes on financial executives' decisions. Strategic Management Journal, 26, 181-95. 
Sutherland, E.H. (1940). White collar criminality. American Sociological Review, 5, 112.

Sutherland, E.H.. (1983). White Collar Crime: The uncut version. New Haven: Yale University Press.

Tourangeau, R., Rips, L.J., \& Rasinksi, K. (2000). The Psychology of Survey Response. Cambridge: Cambridge University Press.

Treviño, L.K. (1986). Ethical decision making in organizations: A person-situation interactionist model. Academy of Management Review, 11, 601-17.

Treviño, L.K., Brown, M., \&, Hartman L.P. (2003). A qualitative investigation of perceived executive ethical leadership: Perceptions from inside and outside the executive suite. Human Relations, 56, 5-37.

Treviño, L.K., \& Butterfield, K.D., \& McCabe, D.L. (1998). The ethical context in organizations: Influences on employee attitudes and behaviors. Business Ethics Quarterly, 8, 447-76.

Treviño, L.K., Hartman, L.P., \& Brown, M. (2000). Moral person and moral manager: How executives develop a reputation for ethical leadership. California Management Review, 42, 128-42.

Treviño, L.K., \& Victor, B. (1992). Peer reporting of unethical behavior: a social context perspective. Academy of Management Journal, 35, 38-64.

Treviño, L.K., \& Weaver, G.R. (2001). Organizational justice and ethics program "follow through": influences on employees' harmful and helpful behavior. Business Ethics Quarterly, 11, 651-71.

Treviño, L.K., \& Weaver, G.R. (2003). Managing Ethics in Business Organizations: Social scientific perspectives. Stanford: Stanford University Press. 
Treviño, L.K., Weaver, G., Gibson, D., \& Toffler, B. (1999). Managing ethics and legal compliance: what works and what hurts. California Management Review, 41, 131-51.

Treviño, L.K., \& Youngblood, S.A. (1990). Bad apples in bad barrels: A causal analysis of ethical decision-making behavior. Journal of Applied Psychology, 75, 378-85.

Tyler, T.R., \& Blader, S.L. (2005). Can business effectively regulate employee conduct? The antecedents of rule following in work settings. Academy of Management Journal, 6, 1143-58.

Velasquez, M.G. (2002). Business Ethics: Concepts and cases. New York: Prentice Hall.

Victor, B., \& Cullen, J.B. (1987). A theory and measure of ethical climate in organizations. Research in Corporate Social Performance and Policy, 9, 51-71.

Victor, B., \& Cullen, J.B. (1988). The organizational bases of ethical work climates. Administrative Science Quarterly, 33, 101-25.

Weber, J. (1995). Influences upon organizational ethical subclimates: A multidepartmental analysis of a single firm. Organization Science, 6, 509-23.

Wimbush, J.C., Shepard, J.M., \& Markham, S.E. (1997). An empirical examination of the multi-dimensionality of ethical climate in organizations. Journal of Business Ethics, 16, 67-77.

Zey-Ferrell, M., \& Ferrell, O.C. (1982). Role-set configurations and opportunities as predictors of unethical behavior in organizations. Human Relations, 32, 587-60. 
Table 1. Pattern matrix of rotated factor loadings from the exploratory factor analysis of all ethical organizational culture items $(\mathrm{N}=242)$

\begin{tabular}{|c|c|c|c|c|c|c|c|c|}
\hline \multirow[b]{5}{*}{$\begin{array}{l}\text { 1.1. The organization makes it sufficiently clear to me how I } \\
\text { should conduct myself appropriately toward others within the } \\
\text { organization }\end{array}$} & \multicolumn{8}{|c|}{ Corporate ethical virtue constructs } \\
\hline & \multirow[b]{3}{*}{ 1. Clarity } & \multirow{3}{*}{$\begin{array}{l}\text { 2. Congruency } \\
\text { of supervisors }\end{array}$} & \multirow{3}{*}{$\begin{array}{l}\text { 3. Congruency } \\
\text { of } \\
\text { management }\end{array}$} & \multirow{2}{*}{\multicolumn{5}{|c|}{$\begin{array}{c}6 . \\
\text { Transpare }\end{array}$}} \\
\hline & & & & & & & & \\
\hline & & & & 4. Feasibility & 5. Supportability & ncy & 7. Discussability $8 . \subseteq$ & Sanctionability \\
\hline & .60 & .13 & -.13 & -.018 & .01 & -.14 & .05 & .03 \\
\hline $\begin{array}{l}\text { 1.2. The organization makes it sufficiently clear to me how I } \\
\text { should obtain proper authorizations }\end{array}$ & .68 & .06 & -.03 & .07 & -.07 & -.01 & -.05 & -.12 \\
\hline $\begin{array}{l}\text { 1.3. The organization makes it sufficiently clear to me how I } \\
\text { should use company equipment responsibly }\end{array}$ & .69 & .06 & -.04 & .10 & .13 & -.17 & -.05 & .04 \\
\hline $\begin{array}{l}\text { 1.4. The organization makes it sufficiently clear to me how I } \\
\text { should use my working hours responsibly }\end{array}$ & .67 & .07 & .08 & -.01 & .07 & .08 & .21 & .03 \\
\hline $\begin{array}{l}\text { 1.5. The organization makes it sufficiently clear to me how I } \\
\text { should handle money and other financial assets responsibly }\end{array}$ & .70 & .01 & .08 & -.01 & -.07 & .12 & -.01 & -.12 \\
\hline $\begin{array}{l}\text { 1.6. The organization makes it sufficiently clear to me how I } \\
\text { should deal with conflicts of interests and sideline activities } \\
\text { responsibly }\end{array}$ & .69 & -.07 & -.09 & .13 & -.03 & .01 & -.01 & .01 \\
\hline $\begin{array}{l}\text { 1.7. The organization makes it sufficiently clear to me how I } \\
\text { should deal with confidential information responsibly }\end{array}$ & .74 & -.02 & -.09 & .03 & -.09 & .06 & .12 & .01 \\
\hline $\begin{array}{l}\text { 1.8. The organization makes it sufficiently clear to me how I } \\
\text { should deal with external persons and organizations responsibly }\end{array}$ & .72 & .09 & -.12 & -.07 & -.03 & -.14 & -.13 & -.03 \\
\hline $\begin{array}{l}\text { 1.9. The organization makes it sufficiently clear to me how I } \\
\text { should deal with environmental issues in a responsible way }\end{array}$ & .56 & -.01 & -.11 & -.05 & .01 & -.11 & -.12 & -.13 \\
\hline $\begin{array}{l}\text { 1.10. In my immediate working environment, it is sufficiently } \\
\text { clear how we are expected to conduct ourselves in a responsible } \\
\text { way }\end{array}$ & .54 & .11 & -.24 & -.02 & .01 & -.21 & -.05 & -.04 \\
\hline $\begin{array}{l}\text { 2.1. My supervisor sets a good example in terms of ethical } \\
\text { behavior }\end{array}$ & .06 & .81 & -.02 & .05 & -.01 & .02 & .03 & .02 \\
\hline $\begin{array}{l}\text { 2.2. My supervisor communicates the importance of ethics and } \\
\text { integrity clearly and convincingly }\end{array}$ & .20 & .65 & -.05 & .06 & -.07 & -.05 & .10 & .09 \\
\hline $\begin{array}{l}\text { 2.3. My supervisor would never authorize unethical or illegal } \\
\text { conduct to meet business goals }\end{array}$ & .10 & .65 & -.03 & -.07 & -.18 & .03 & .05 & -.11 \\
\hline 2.4. My supervisor does as he says & -.04 & .89 & .01 & .11 & .03 & -.03 & -.02 & .01 \\
\hline
\end{tabular}


3.1. The conduct of the Board and (senior) management reflects a shared set of norms and values

3.2. The Board and (senior) management sets a good example in terms of ethical behavior

3.3. The Board and (senior) management communicates the importance of ethics and integrity clearly and convincingly

3.4. The Board and (senior) management would never authorize unethical or illegal conduct to meet business goals

4.1. In my immediate working environment, I am sometimes asked to do things that conflict with my conscience ${ }^{a}$

4.2. In order to be successful in my organization, I sometimes have to sacrifice my personal norms and values ${ }^{\mathrm{a}}$

4.4. I have insufficient information at my disposal to carry out my tasks responsibly

5.2. In my immediate working environment, an atmosphere of mutual trust prevails 
5.6. In my immediate working environment, everyone treats one another with respect

6.1. If a colleague does something which is not permitted, my manager will find out about it

6.2. If a colleague does something which is not permitted, I or another colleague will find out about it

6.3. If my manager does something which is not permitted,

someone in the organization will find out about it

6.4. If I criticize other people's behavior, I will receive feedback on any action taken as a result of my criticism

6.5. In my immediate working environment, there is adequate

awareness of potential violations and incidents in the

organization

6.6. In my immediate working environment, adequate checks are carried out to detect violations and unethical conduct

6.7. Management is aware of the type of incidents and unethical conduct that occur in my immediate working environment

7.1. In my immediate working environment, reports of unethical conduct are handled with caution

7.2. In my immediate working environment, I have the opportunity to express my opinion

7.3. In my immediate working environment, there is adequate scope to discuss unethical conduct

7.4. In my immediate working environment, reports of unethical conduct are taken seriously

7.5. In my immediate working environment, there is adequate scope to discuss personal moral dilemmas

7.6. In my immediate working environment, there is adequate scope to report unethical conduct

7.7. In my immediate working environment, there is ample opportunity for discussing moral dilemmas

7.8. If someone is called to account for his/her conduct, it is done in a respectful manner

7.9. In my immediate working environment, there is adequate scope to correct unethical conduct 
7.10. If reported unethical conduct in my immediate working environment does not receive adequate attention, there is sufficient opportunity to raise the matter elsewhere in the organization

8.1. In my immediate working environment, people are accountable for their actions

8.2. In my immediate working environment, ethical conduct is valued highly

8.3. In my immediate working environment, only people with integrity are considered for promotion

8.4. If necessary, my manager will be disciplined if $\mathrm{s} / \mathrm{he}$ behaves unethically

8.5. The people that are successful in my immediate working environment stick to the norms and standards of the organization 8.6. In my immediate working environment, ethical conduct is rewarded

8.7. In my immediate working environment, employees will be disciplined if they behave unethically

8.8. If I reported unethical conduct to management, I believe those involved would be disciplined fairly regardless of their position

8.9. In my immediate working environment, employees who conduct themselves with integrity stand a greater chance to receive a positive performance appraisal than employees who

conduct themselves without integrity

\section{Personal eigenvalues}


Table 2. Results of confirmatory analysis of corporate ethical virtue constructs $(\mathrm{N}=312)$

\begin{tabular}{|c|c|c|c|c|c|c|c|c|c|c|c|}
\hline & $\begin{array}{l}\text { Number } \\
\text { of items }\end{array}$ & $\begin{array}{c}\text { Cronbach } \\
\text { 's } \\
\text { alpha }\end{array}$ & GFI & $A G F I$ & PGFI & RMSR & RMSEA & CFI & $\chi^{2}$ & $D f$ & Sig. \\
\hline Clarity & 10 & .93 & .99 & .99 & .77 & .05 & .00 & .95 & 75.00 & 35 & .00 \\
\hline Congruency of supervisors & 6 & .95 & .99 & .99 & .60 & .04 & .00 & .89 & 181.68 & 9 & .00 \\
\hline Congruency of management & 4 & .95 & .99 & .99 & .33 & .01 & .00 & .99 & 4.73 & 2 & .00 \\
\hline Feasibility & 6 & .96 & .99 & .99 & .60 & .02 & .00 & .97 & 59.76 & 9 & .00 \\
\hline Supportability & 6 & .95 & .99 & .99 & .60 & .01 & .00 & .99 & 28.19 & 9 & .00 \\
\hline Transparency & 7 & .93 & .99 & .99 & .66 & .04 & .00 & .94 & 92.71 & 14 & .00 \\
\hline Discussability & 10 & .94 & .99 & .99 & .77 & .04 & .01 & .92 & 282.65 & 35 & .00 \\
\hline Sanctionability & 9 & .94 & .99 & .99 & .75 & .04 & .00 & .94 & 202.97 & 27 & .00 \\
\hline
\end{tabular}

Number of items is the number of items after scale analysis. Cronbach's alpha refers to the raw (non-weighted) scale reliability. GFI is the Goodness-of-Fit Index. AGFI is the Adjusted Goodness-of-Fit Index. PGFI is James. Mulaik and Brett's (1982) Parsimonious GFI. RMSR refers to the Root Mean Square Residual. RMSEA refers to the Root Mean Square Error of Approximation. CFI is Bentler's (1989) Comparative Fit Index. $\chi^{2}$ is the observed chi-square statistic for a test of the assumed factor model; DF is its degrees of freedom and Sig. is the associated significance level. 
Figure 1. Results of the second-order confirmatory factor analysis $(\mathrm{N}=312)$

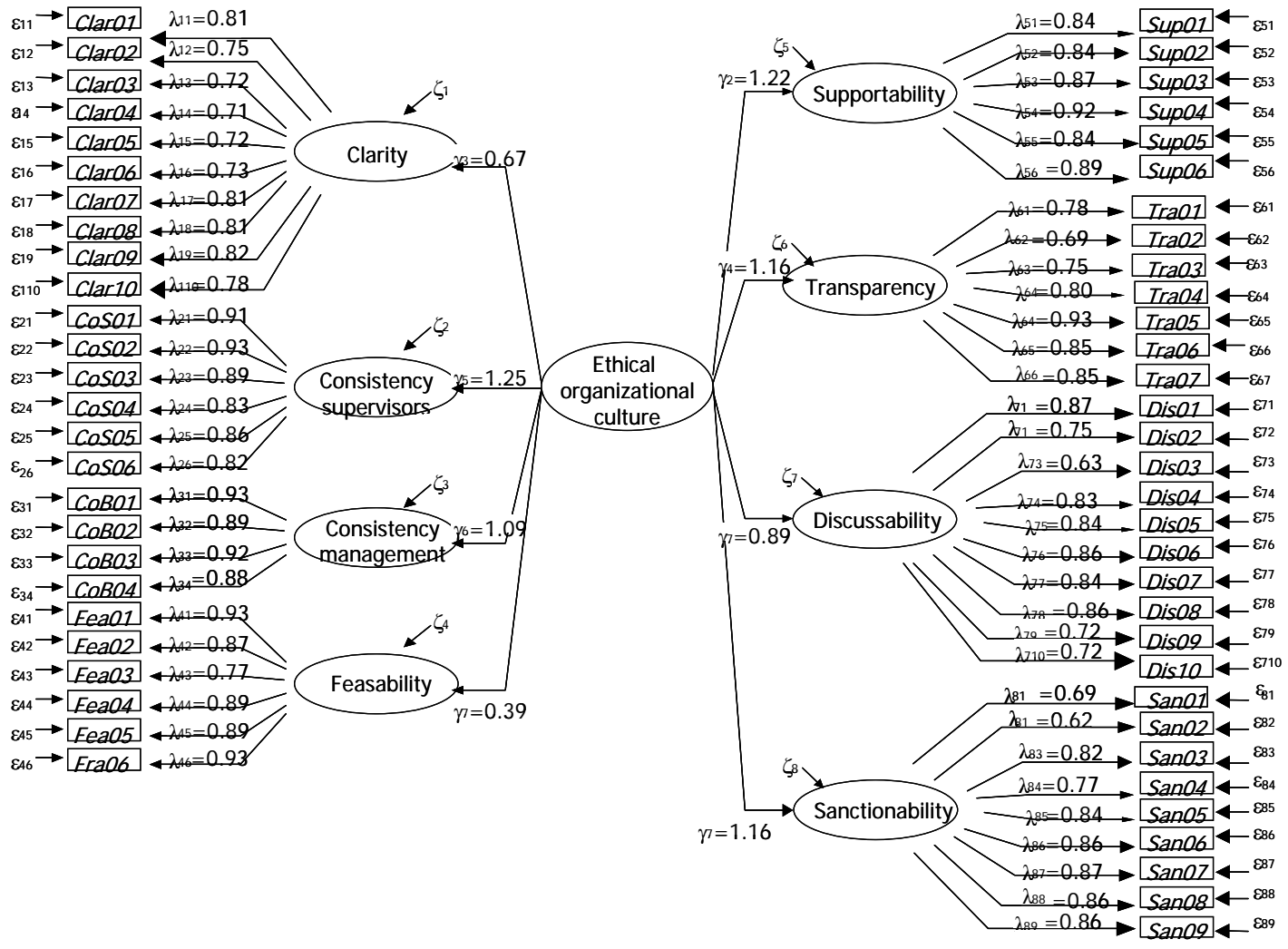


Table 3. Within-group consistency analysis for three companies $(\mathrm{N}=235)$

\begin{tabular}{lccc}
\hline & & $R w g$ & Average \\
Corporate ethical virtue & Minimum & & Maximum \\
\cline { 2 - 4 } constructs & & .88 & .83 \\
Clarity & .75 & .80 & .78 \\
Congruency of supervisors & .73 & .77 & .65 \\
Congruency of management & .41 & .93 & .89 \\
Feasibility & .87 & .87 & .83 \\
Supportability & .77 & .83 & .79 \\
Transparency & .78 & .88 & .82 \\
Discussability & .78 & .86 & .82 \\
Sanctionability & .74 & & .82 \\
\hline
\end{tabular}


Table 4. Results of MANOVA by company $(\mathrm{N}=235)$

\begin{tabular}{|c|c|c|}
\hline Company effect & Wilks' Lambda $=8.10 \quad F=6.68$ & $P<.001$ \\
\hline & \multicolumn{2}{|c|}{ Univariate results } \\
\hline Variable & $F$ & $P<$ \\
\hline Clarity & 6.51 & .01 \\
\hline Congruency of supervisors & 1.09 & .34 \\
\hline Congruency of management & 5.70 & .01 \\
\hline Feasibility & 2.71 & .07 \\
\hline Supportability & 13.77 & .00 \\
\hline Transparency & 7.10 & .01 \\
\hline Discussability & 2.82 & .06 \\
\hline Sanctionability & 3.00 & .05 \\
\hline
\end{tabular}

\section{Means}

Company

\begin{tabular}{ccccccc}
\hline & Congruency & Congruency & & & \\
Clarity & of supervisors & of & Feasibility & Supportability & Transparency & Discussability \\
\end{tabular}


management

\begin{tabular}{lccccccccc}
\hline Electronics Retail Store & 5.0 & 4.9 & 4.7 & 3.7 & 4.8 & 4.4 & 4.8 & 4.3 & 4.6 \\
Security Company & 4.6 & 4.7 & 4.1 & 3.4 & 4.1 & 3.7 & 4.5 & 4.3 \\
Waterworks & 4.4 & 4.6 & 4.5 & 3.4 & 4.6 & 4.1 & 4.8 & 4.6 \\
\hline
\end{tabular}

${ }^{1}$ Of the ten academic experts, eight were Dutch. Of the ten companies, five were European, three were American, one was African and one was Australian. All 15 management consultants were working for KPMG in the field of ethics, compliance and integrity: five were European, four were American, three were African, two were Australian and one was Asian.

${ }^{2}$ Following the suggestions of Harkness and Schoua (1998), the questionnaire was translated to Dutch by the author who grew up in the Netherlands. Two bilingual colleagues also independently translated the questionnaire into Dutch after which the three versions were discussed in order to produce a consensual version. Blind to the original questionnaire, a professional translator translated the Dutch questionnaire back into English. The author and the translator compared the back-translated text for inconsistencies with the original version in order to finalize the Dutch version. A version of the Dutch survey is available upon request from the author. 


\section{Publications in the ERIM Report Series Research* in Management}

\section{ERIM Research Program: "Organizing for Performance"}

2007

Leadership Behaviour and Upward Feedback: Findings From a Longitudinal Intervention

Dirk van Dierendonck, Clare Haynes, Carol Borrill and Chris Stride

ERS-2007-003-ORG

http://hdl.handle.net/1765/8579

The Clean Development Mechanism: Institutionalizing New Power Relations

Bettina B.F. Wittneben

ERS-2007-004-ORG

http://hdl.handle.net/1765/8582

How Today's Consumers Perceive Tomorrow's Smart Products

Serge A. Rijsdijk and Erik Jan Hultink

ERS-2007-005-ORG

http://hdl.handle.net/1765/8984

Product Intelligence: Its Conceptualization, Measurement and Impact on Consumer Satisfaction

Serge A. Rijsdijk, Erik Jan Hultink and Adamantios Diamantopoulos

ERS-2007-006-ORG

http://hdl.handle.net/1765/8580

Testing the Strength of the Iron Cage: A Meta-Analysis of Neo-Institutional Theory

Pursey P.M.A.R. Heugens and Michel Lander

ERS-2007-007-ORG

http://hdl.handle.net/1765/8581

Export Orientation among New Ventures and Economic Growth

S. Jolanda A. Hessels and André van Stel

ERS-2007-008-ORG

http://hdl.handle.net/1765/8583

Allocation and Productivity of Time in New Ventures of Female and Male Entrepreneurs

Ingrid Verheul, Martin Carree and Roy Thurik

ERS-2007-009-ORG

http://hdl.handle.net/1765/8989

Cooperating if one's Goals are Collective-Based: Social Identification Effects in Social Dilemmas as a Function of Goal-Transformation David De Cremer, Daan van Knippenberg, Eric van Dijk and Esther van Leeuwen

ERS-2007-010-ORG

http://hdl.handle.net/1765/9041

Unfit to Learn? How Long View Organizations Adapt to Environmental Jolts

Pursey P. M. A. R. Heugens and Stelios C. Zyglidopoulos

ERS-2007-014-ORG

http://hdl.handle.net/1765/9404

Going, Going, Gone. Innovation and Exit in Manufacturing Firms

Elena Cefis and Orietta Marsili

ERS-2007-015-ORG

http://hdl.handle.net/1765/9732 
High in the Hierarchy: How Vertical Location and Judgments of Leaders' Power are Interrelated

Steffen R. Giessner and Thomas W. Schubert

ERS-2007-021-ORG

http://hdl.handle.net/1765/9727

Contracts to Communities: a Processual Model of Organizational Virtue

Pursey P.M.A.R. Heugens, Muel Kaptein and J. van Oosterhout

ERS-2007-023-ORG

http://hdl.handle.net/1765/9728

Why Are Some Entrepreneurs More Innovative Than Others?

Philipp Koellinger

ERS-2007-024-ORG

http://hdl.handle.net/1765/9730

Stimulating Strategically Aligned Behaviour Among Employees

Cees B. M. van Riel, Guido Berens and Majorie Dijkstra

ERS-2007-029-ORG

http://hdl.handle.net/1765/10067

The Effectiveness of Business Codes: A Critical Examination of Existing Studies and the Development of an Integrated Research Model

Muel Kaptein and Mark Schwartz

ERS-2007-030-ORG

http://hdl.handle.net/1765/10150

Knowledge Spillovers and Entrepreneurs' Export Orientation

Dirk De Clercq, Jolanda Hessels and André van Stel

ERS-2007-038-ORG

http://hdl.handle.net/1765/10178

Silicon Valley in the Polder? Entrepreneurial Dynamics, Virtuous Clusters and Vicious Firms in the Netherlands and Flanders Willem Hulsink, Harry Bouwman and Tom Elfring

ERS-2007-048-ORG

http://hdl.handle.net/1765/10459

An Incomplete Contracting Model of Governance Structure Variety in Franchising

George Hendrikse and Tao Jiang

ERS-2007-049-ORG

http://hdl.handle.net/1765/10462

On the Evolution of Product Portfolio Coherence of Cooperatives versus Corporations: An Agent-Based Analysis of the Single Origin Constraint

George Hendrikse and Ruud Smit

ERS-2007-055-ORG

http://hdl.handle.net/1765/10505

Greenfield or Acquisition Entry: A Review of the Empirical Foreign Establishment Mode Literature

Arjen H.L. Slangen and Jean-François Hennart

ERS-2007-059-ORG

http://hdl.handle.net/1765/10539

Do Multinationals Really Prefer to Enter Culturally-Distant Countries Through Greenfields Rather than Through Acquisitions?

The Role of Parent Experience and Subsidiary Autonomy

Arjen H.L. Slangen and Jean-François Hennart

ERS-2007-060-ORG

http://hdl.handle.net/1765/10538 
The Financial Centres of Shanghai and Hong Kong: Competition or Complementarity?

Bas Karreman and Bert van der Knaap

ERS-2007-062-ORG

http://hdl.handle.net/1765/10516

Peer Influence in Network Markets: An Empirical Investigation

Jörn H. Block and Philipp Köllinger

ERS-2007-063-ORG

http://hdl.handle.net/1765/10540

Clustering in ICT: From Route 128 to Silicon Valley, from DEC to Google, from Hardware to Content

Wim Hulsink, Dick Manuel and Harry Bouwman

ERS-2007-064-ORG

http://hdl.handle.net/1765/10617

Leader Affective Displays and Attributions of Charisma: The Role of Arousal

Frederic Damen, Daan van Knippenberg and Barbara van Knippenberg

ERS-2007-067-ORG

http://hdl.handle.net/1765/10621

Unity through Diversity: Value-in-Diversity Beliefs, Work Group Diversity, and Group Identification

Daan van Knippenberg, S. Alexander Haslam and Michael J. Platow

ERS-2007-068-ORG

http://hdl.handle.net/1765/10620

Entrepreneurial Diversity and Economic Growth

Ingrid Verheul and André van Stel

ERS-2007-070-ORG

http://hdl.handle.net/1765/10619

Commitment or Control? Human Resource Management Practices in Female and Male-Led Businesses

Ingrid Verheul

ERS-2007-071-ORG

http://hdl.handle.net/1765/10618

Allocation of Decision Rights in Fruit and Vegetable Contracts in China

Yamei Hu and George Hendrikse

ERS-2007-077-ORG

http://hdl.handle.net/1765/10717

The Role of Transformational Leadership in Enhancing Team Reflexivity

Michaéla C. Schippers, Deanne N. Den Hartog, Paul L. Koopman and Daan van Knippenberg

ERS-2007-080-ORG

http://hdl.handle.net/1765/10720

Developing and Testing a Measure for the Ethical Culture of Organizations: The Corporate Ethical Virtues Model

Muel Kaptein

ERS-2007-084-ORG

http://hdl.handle.net/1765/10770

Postcards from the Edge: A Review of the Business and Environment Literature

Luca Berchicci and Andrew King

ERS-2007-085-ORG

http://hdl.handle.net/1765/10771

Spiraling Down into Corruption: A Dynamic Analysis of the Social Identity Processes that Cause Corruption in Organizations to Grow

Niki A. Den Nieuwenboer and Muel Kaptein

ERS-2007-086-ORG

http://hdl.handle.net/1765/10772 
* A complete overview of the ERIM Report Series Research in Management: https://ep.eur.nl/handle/1765/1

ERIM Research Programs:

LIS Business Processes, Logistics and Information Systems ORG Organizing for Performance

MKT Marketing

F\&A Finance and Accounting

STR Strategy and Entrepreneurship 